\title{
Popular Participation in the Elaboration of Urban Planning Tools in Algeria. The Case of Blida State
}

\author{
Karim IKHLEFHOUM*1, Mahfoud ZIANE ${ }^{*}$ \\ ${ }^{*}$ Corresponding author \\ ${ }^{1}$ University of Science and Technology, Houari-Boumédiène (FSTGAT-USTHB), Faculty of Earth Sciences, Geography and Spatial \\ Planning, Laboratory of Cities, Region, and Territorial Governance (LVRGT), Algiers, ALGERIA \\ E-mail: medinavilles@yahoo.fr, zianmadz@yahoo.fr \\ DOI: 10.24193/JSSP.2019.1.01 \\ https://doi.org/10.24193/JSSP.2019.1.01
}

K e y w o r d s: urban planning, planning tools, popular participation, urbanization, urban issues, Algeria

\begin{abstract}
A B S T RA C T
This paper aims to evaluate popular participation in the preparation of urban planning tools in Algeria by highlighting methods, levels and means of implementation. A study has been conducted in the most important municipalities of the State of Blida: Larbaâ, Bouguerra, El Afroun and Guerouaoua during the years of 2016-2017. Algeria has used popular participation in the preparation of urban planning tools since 1990. However, it remains symbolic. We put forward some hypotheses that reflect different factors of symbolic participation, as follows: popular participation is linked to the legal framework that regulates urban planning, the efficiency of urban planning in Algeria is related to the degree of urban awareness of Algerian citizens, and at last but not at least, the power of popular participation is rooted in and is directly related to the factor of trust between local authorities and the citizen. Overall, this research aims to analyze and evaluate the operation of popular participation in the elaboration of urban planning tools in Algeria, and to offer some recommendations and proposals so as to increase the efficiency of popular participation in urban planning. In order to reach these goals, we relied on the theoretical as well as the practical approaches by presenting basic concepts, principles and the levels of popular participation with further projection on the area of study compared to some international experiments. Through this study, we were able to evaluate that popular participation in the preparation of urban planning tools in Algeria is inefficient, just formal and does not reach the level where it enables to make significantly important decisions in urban planning. In order to increase efficiency, we ought to modify the regulatory framework regarding the operation of urban planning, by integrating popular participation before even beginning to prepare the urban planning tools.
\end{abstract}

\section{INTRODUCTION}

Urban planning tools are part of the organizational and operational structure of the city and its area, used in many countries of the world in their various political systems (Hattab, 2014) and aims to design the best spatial and social conditions for the creation and management of cities or functional areas of urbanization. It can be considered as a planning and regulatory tool that allows public authorities to control growth and urbanization, through the implementation of factors in the management of disciplines, which are often used as a mechanism in planning studies (Mosilhi, 2008).

Popular participation is one of the most important steps in the preparation of urban planning tools. The urban plans which have been designed to solve problems without taking into account public participation were impossible to implement (Weingran, 2007) and Algeria, like other nations in the world, 
adopted popular participation in the preparation of urban planning tools since 1990 (Law no. 90-29, 1990).

Even though almost 30 years have passed since the adoption of the method of popular participation in the preparation of urban planning tools in Algeria, it plays a secondary and insignificant role in the completion and preparation of urban development plans. The situation in the field of research in some municipalities of Blida province reflects the problem of the ineffectiveness and the lack of contribution of popular participation in the preparation of urban planning, which raises the following questions: What are the obstacles to implementing popular participation in the preparation of urban planning tools in Algeria? Does the urban legislative system give a secondary role to popular participation in the preparation of various urban planning blueprints? Is the deficit in popular participation in the preparation of urban schemes due to the responsibility of the community or the responsibility of the Algerian public authorities?

Popular participation is regarded as one of the fundaments for the development and improvement of societies, participation being both a purpose and a means at the same time; a purpose for the promotion of solidarity among the citizens and the strengthening of their nationalism by involving them in programs that serve the local society, as well as a means to contribute in the realization of durable urban development. The implementation of popular participation in different local urban programs and projects is considered a practical application of the notion of popular labor that is based on will and choice instead of coercion, through which we can benefit from the efforts and the latent potential of the locals, thereby reducing the expenses of the government.

The effectiveness of popular participation in urban planning correlates with the local population's awareness of the issues of urban development, as well as the degree of trust between the inhabitants and the local authorities. The later is a fundamental factor for the achievement of the purposes of the participation because lack of trust between the two parties weakens the quality of the participation in the projects related to urban planning.

\section{STUDY AREA}

The province of Blida is a crossroads of exchanges between the north and the south, the east, and the west. It is also spacious, with exceptional agricultural potential, threatened by a very dynamic urbanization. It is situated in a geostrategic position at the Algerian level and it benefits from the most helpful accessibility (located at $35 \mathrm{~km}$ from the port, $40 \mathrm{~km}$ from the airport and it is connected by the railway to the various provinces of the north). This accessibility is comforted by the east-west highway and the road network connecting this space to the capital. With more than one million inhabitants in the last census as shown in Figure 2 (National Statistical Office, 2008), the province of Blida, by its economic and demographic weight, is a territory of significant size. Its chief town is the second largest pole in the metropolitan area of Algeria (National Land Use Planning Agency, 2012).

This paper is based on the study of some of Blida's municipalities: Blida, Larbaâ, Boufarik, Bougara, El-Afroun and Guerrouaou, as shown in Figure 1.

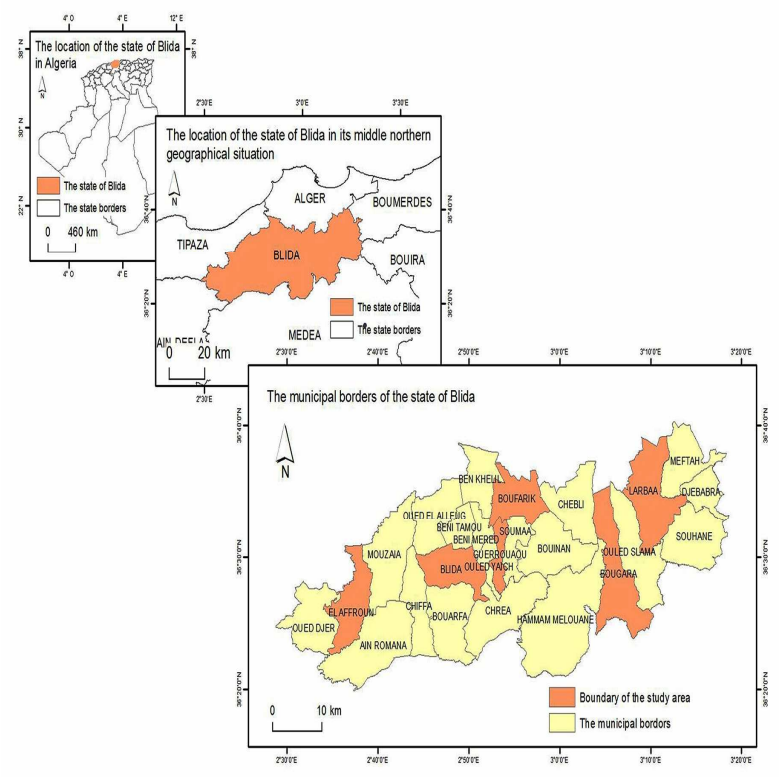

Fig. 1. Location of the study area.

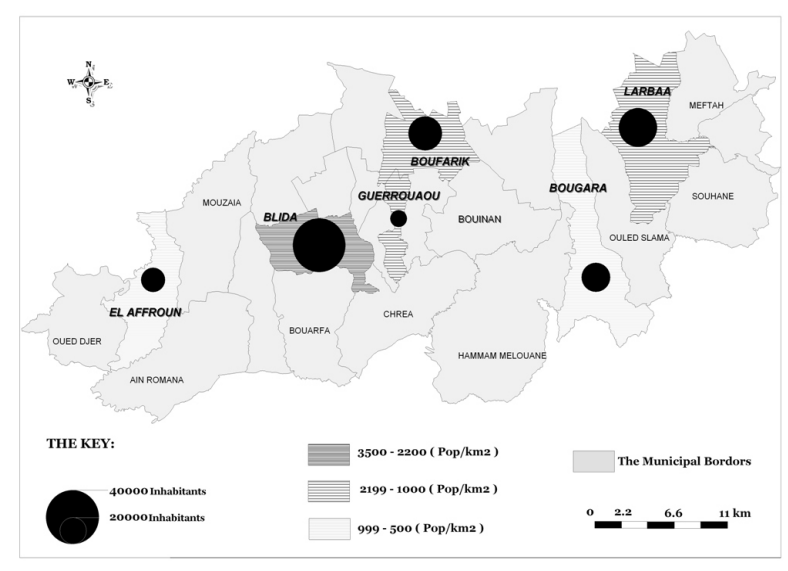

Fig. 2. The distribution of the population in the study area and its population density.

\section{THEORY AND METHODOLOGY}

Based on the nature of the subject which is related to the study and evaluation of the experience of popular participation in the preparation of urban planning tools in Algeria through the case study of some municipalities in the State of Blida, this research paper presents some notions and principles related to 
population participation and its levels of implementations. In addition, it examines the urban planning tools in Algeria by studying the method of implementation of popular participation in the preparation of urban plans and projects as well as the legislative framework organizing the urban planning operations in Algeria.

We also relied on the experience of some countries throughout the world for the method of implementation of popular participation in urban planning and projects. In the light of the goals of this study, we adopted the analytical descriptive approach in order to describe and evaluate the experience of popular participation in the preparation of urban planning tools in Algeria. In this context, we conducted sample surveys by distributing 25,000 survey samples with close ended questions in the municipalities of Blida, Larbaâ, Boufarik, Bougara, el Afroun and Guerrouaou between 2016-2017. We got responses to 24,554 samples which equals about $5.08 \%$ of the total population of the municipalities (taking into consideration that the number of inhabitants reached 48,375 people in 2015) (Official Bulletin of the State of Blida, No. 23 of September 20 $^{\text {th }}$ 2018). Afterwards the results of the surveys were compiled with a Geographic Information System (SIG) which is ARCGIS number 10.5 and using the thematic analysis in the ARC GIS software, we were able to present the results poll in the form of maps which reflected the hypothesis and the results of the research.

In addition, we interviewed some local officials to identify the obstacles to popular participation in urban planning and raised with them the issues and problems related to urban planning wich we observed during our multiple visits to the municipalities of the study area.

\subsection{Popular participation: concept, principles and levels of application}

The concept of popular participation in the field of urban planning has been extended due to the increasing criticism of the normative legal and technocratic model of urban planning, characterized by the dominance and domination of public authority in the planning and management of the urban area; and within this climate, new trends have emerged calling for the involvement of individuals of the local urban society in the design and preparation of urban development plans to forge a common view among the population, the planners and public authorities, and economic actors for the future of their neighborhoods or city (Forester, 1988).

It is the involvement of all parties concerned with development based on an awareness of the issue and the interests of the various parties, in an ongoing process of negotiation and decision-making and all that this implies for every party, including the use of every local resource available (Salama, 2010). In the field of urban management, it is synonymous with the concept of good governance, calling upon a participatory local democratic ideology, where people take part in all decisions and become real actors at all stages of the urban project (Bouzahzah and Bouzahzah, 2008), as for the principles and basics of popular participation, they are expounded in Figure 3.

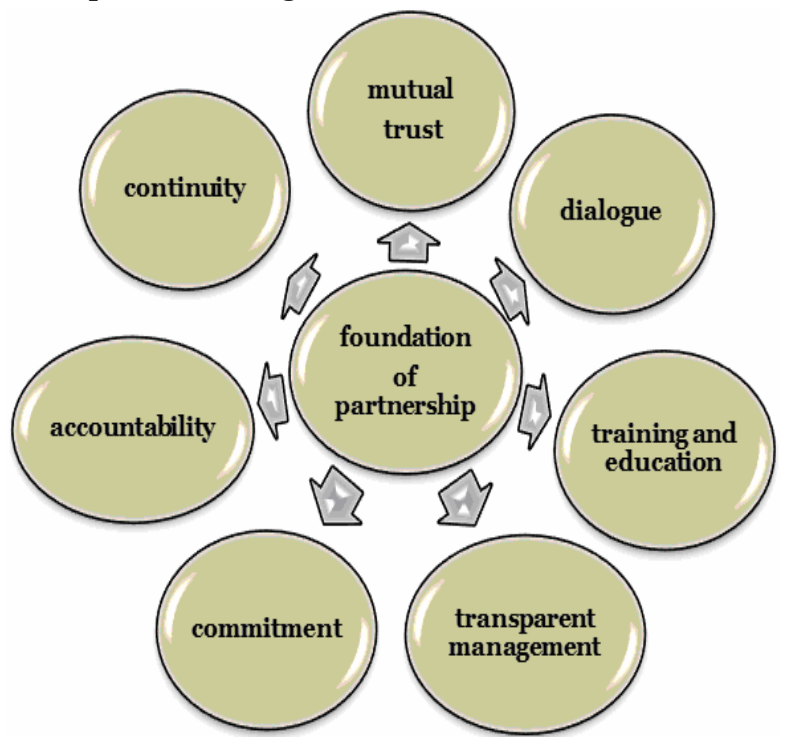

Fig. 3. Principles and basics of popular participation (source: Habib, 2009).

Various levels of popular participation are observed on the field while executing urban planning projects. Participation can be realized on different scales varying from symbolic to actual participation in urban planning. In 1969, Arnstein Cherry proposed a scale with 8 levels showing public participation, based on the extent of power and control. Each level in the scale equals a certain level of popular participation (Table 1).

In this scale, the power of popular participation varies between the citizens' full control, that is, entrusting the participant with full responsibility to make decisions that influence him, and which usually are taken by specialists; followed by symbolic participation, in which participants express their needs to the local authorities. Control and decision-making at this scale are held by the local authorities. At last, absence of participation is represented in the first and second levels of the scale, where the participant or citizen is only given the impression of satisfaction and encouraged to execute urban projects without his slightest awareness of it.

In 1989, the UNO classified levels of participation by developing three models that reflect the different orientations related to the execution of any project (United Nations Centre for Human Settlements, 1989). These models are: 
a). The Participatory Model: according to this model, locals are intensely involved in planning and executing projects. Decisions are made through discussions between locals and specialists. This model reflects a high degree of popular participation, affirming that solving the problem and decision-making are on the level of society.

b). The Consulting Model: implies that the locals participate in decision-making but in varying degrees. Sometimes, the specialists reach a decision by negotiating with the locals. Other times, projects are presented to the locals and the specialists collect their comments. Then, the specialists take decisions in the light of these comments; but not necessarily in accordance with the locals' wishes.

c). The Transmittal Model: Specialists propose their plans to local authorities. Once they are approved, the social actors inform the inhabitants about plans and how they will be executed. In this model, choices are not given to the inhabitants and the plans are not subject to any modifications. This model does not reflect any degree of participation; that is, the participant is absent.

Table 1. People's participation levels.

\begin{tabular}{|c|c|c|}
\hline No. & Method of participation & Level of participation \\
\hline $\mathbf{1}$ & $\begin{array}{l}\text { Manipulation: Give the impression to the citizens that they are involved in an } \\
\text { operation without the slightest awareness of them }\end{array}$ & \multirow{2}{*}{$\begin{array}{l}\text { Absence of participation: } \\
\text { The goal is not to involve the citizens in } \\
\text { the planning but assuring their } \\
\text { submission and setting control over } \\
\text { them }\end{array}$} \\
\hline 2 & $\begin{array}{l}\text { Therapy: Meetings with citizens without addressing the real problems and } \\
\text { challenges }\end{array}$ & \\
\hline 3 & $\begin{array}{l}\text { Information: Citizens are informed of plans and projects without the ability to } \\
\text { express their opinion }\end{array}$ & \multirow{3}{*}{$\begin{array}{l}\text { Symbolic participation: } \\
\text { This level enables citizens to get access } \\
\text { and listen to information and at the same } \\
\text { time to make their opinion heard }\end{array}$} \\
\hline 4 & $\begin{array}{l}\text { Consultation: To conduct public meetings or investigations that allow citizens to } \\
\text { express their views, which are often not considered or taken into account }\end{array}$ & \\
\hline 5 & $\begin{array}{l}\text { Appeasement: Some people are involved in decisions and have an impact on } \\
\text { project implementation }\end{array}$ & \\
\hline 6 & $\begin{array}{l}\text { Partnership: The decision is the result of negotiations between public authorities } \\
\text { and citizens }\end{array}$ & \multirow{3}{*}{$\begin{array}{l}\text { Actual authority of the citizen: } \\
\text { Citizens have influence over decisions, } \\
\text { they are partners who can negotiate and } \\
\text { exchange views with traditional decision } \\
\text { centers }\end{array}$} \\
\hline 7 & $\begin{array}{l}\text { Delegation: Central authority delegates to a local group the authority to choose } \\
\text { and implement urban plans }\end{array}$ & \\
\hline 8 & $\begin{array}{l}\text { The control of citizens: Where a local group manages independently urban } \\
\text { operations. }\end{array}$ & \\
\hline
\end{tabular}

\subsection{Urban planning tools in Algeria}

It is a tool for programming and organization that allows the public authorities to control urban growth and expansion through legislative and regulatory texts governing the field, as well as the structural and detailed plans, control and planning standards such as the land occupancy factor and the various construction licensing. And according to the Algerian legislation (Law no.06-06, 2006), this tool is the blueprint for amelioration, land tenure schemes and new city-planning schemes, as well as regional schemes, especially those relating to environmental protection and physical heritage, such as the permanent scheme for conservation and rehabilitation of reserved sectors, archaeological sites (Fig. 4), and the green space management scheme, the municipal waste management scheme, as well as the instruments of partnership, information, follow-up, evaluation and financing.

The is one of the most important urban planning tools in Algeria, which is the bedrock on which the rest of the scheme is based, addressing the crosscutting and integrated issues, challenges and stakes of the region (city, municipality, or group of municipalities), besides, the planned scheme is the primary tool for translating regional planning guidelines at the local level.

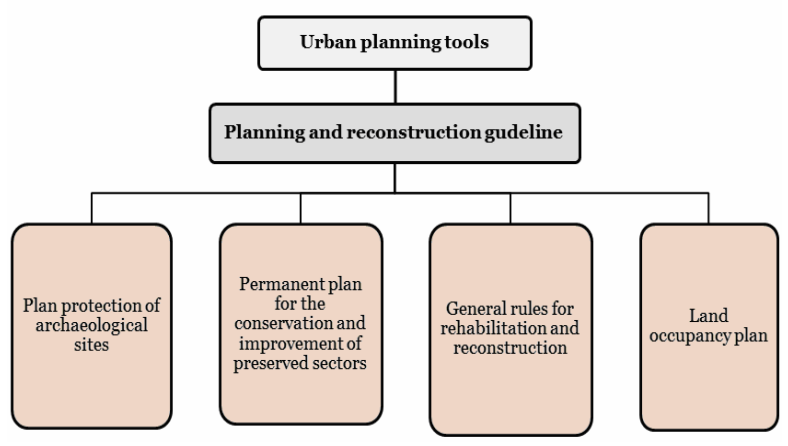

Fig. 4. Urban planning tools in Algeria. (own elaboration based on provisions of Law No. 06-06, 2006).

It aims to determine the general allocation of land, regulate built-up areas and physical tissue to be protected, and coordinate the infrastructure of the networks, facilities, and activities, within appropriate locations according to current and future needs (Adja 
and Drobenko, 2007), and this scheme is prepared in sequential and interrelated stages by diagnosing the current status of the region, and identifying problems and objectives, criteria and parameters for analysis, with a focus on the development of regulatory hypotheses for the region's future in the 20-year horizon, thereby defining its future prospects and its median relationship as a part of the whole at the regional level and as urban textile cell and urbanization at the national level (Saidouni, 2010).

Linking the short and medium-term development and urban planning processes to the 10-year horizon with long-term planning processes (Saidouni, 2010).

\subsection{The method of popular participation in the preparation of the blueprint for space-planning and rehabilitation}

Participation in planning attempts to avoid biased and state-driven planning (Smith, 1973). Urban planning in Algeria involves members of the society in the formulation and conception of urban plans within principles and legal mechanisms represented mainly by media and advertisement, consultation and public investigation.

\subsubsection{Media and advertisement}

The blueprint for space-planning and rehabilitation and the Land Occupancy Scheme are continuously published in order to get approval in places normally reserved for publications concerning citizens belonging to the administration.

The authority that publishes them is committed to respecting their content (Law no. 90-29, 1990) and the space-planning and rehabilitation tools are subject to the widest publicity and are always accessible to the public.

\subsubsection{Counseling}

Local associations for users, chambers of commerce and industry, and professional organizations should be consulted during the preparation of the blueprint for space-planning and rehabilitation, and the land occupancy plan.

\subsubsection{Public investigation}

The approved space-planning and rehabilitation project is submitted by mayor or the presidents of the Municipal People's congresses within 45 days for public inquiry, and the draft should be amended after the public inquiry to take into account, as appropriate, the conclusions of the inquiry (Law no. 90-25, 1990).

\subsection{Experiences of popular participation in urban planning implementation in some countries}

\subsubsection{France}

The participatory dimension of planning has gained importance in the French context over the last two decades. Around 2000, several laws significantly renewed the planning system and led to the rise of territorial governance around large-scale strategic planning projects (Law no. 2000-1208, 2000). Recently, the Grenelle environmental laws (Law no. 2010-788, 2010) fostered the role of sustainability in spatial planning and especially the public consultation instrument (Monédiaire, 2011).

At new larger territorial scales, especially city regions, nature parks, or municipal syndicates, local actors are encouraged to participate in integrated spatial planning and development strategies.

These are jointly developed by local elected representatives in a bottom-up manner, based on negotiation and consensus. However, because strategic planning projects such as those of territorial cohesion schemes (SCOT) greatly depend on local consensus, planning perimeters might significantly vary in size (e.g., 273 municipalities for the Grenoble city region versus sixty-three for the Annecy city region).

\subsubsection{Germany}

Spatial planning in Germany is determined by its federal nature, with a division of competences at three levels: federation, federal states, and municipalities. Even though all levels are interrelated through the "feedback principle", each level has its legal basis (Turowski, 2002). At the federal level, the Spatial Planning Act (2008) sets out guidelines and provisions that coordinate and steer spatial planning, leaving federal states enough scope to legislate in their own interest. The municipalities set up local land-use planning. Public participation has been present in urban planning since the 1970s. Since the implementation of the EU strategic environment Assessment Directive (2001), the public has to be advised of the content of each spatial planning process (Knieling and Othengrafen, 2009). Participation is ensured at the federal state and municipal levels because public participation is a compulsory step in drafting any plan and before adoption (Turowski, 2002).

\subsubsection{Slovenia}

In Slovenia, participation processes have been integrated in spatial development since the 1960s. They were carried out in the form of public displays of land 
use and location plans and public hearings afterwards (Zakon o urbanističnem planiranju, 1967). The Aarhus Convention (1998) has expanded the concept of public participation and exceeds its environmental scope. Its rights-based approach has been integrated into several Slovenian laws that are relevant for sustainable spatial development. Unfortunately, however, the current implementation practice does not follow the legislative framework (Baloh, 2013). The compulsory nature of these provisions gives the false impression that every planning decision is made with public consent. Notably, they are positioned at the very end of the planning process and their role is reduced to granting the process legitimacy by presenting the predetermined proposal to the public. People are thus deprived of the opportunity to contribute effectively and creatively to plans and decisions about their own future and living environment. They can only agree to or oppose the proposed solution (Golobič and Marušič, 2007).

\subsection{Issues and problems relative to urban planning in the study area}

Two basic problems in relation to urban planning are identified in the municipalities of the study area. First, the rates of buildings connected to sewage networks are low (Fig. 5), with an average of 82\% in 2017 (Official Bulletin of the State of Blida, No. 23 of September $20^{\text {th }} 2018$ ), the lowest percentage being recorded in the municipality of Guerouaou with 65.85\% (Technical Department of the Municipality of Guerrouaou, 2017). According to the mayor of this municipality, the problem is due to real-estate issues in the urban spaces, a lot of buildings being without ownership title, in addition to the budget of the municipality which does not cover all the necessities of urban development (Official Statement of the Mayor of Guerrouaou, 2017). The highest percentage of connection to the sewerage network is recorded in the Blida municipality with $90.78 \%$. It remains still low in comparison to the national average reaching $92 \%$ (Official Bulletin of the Ministry of Irrigation no. 38 of February $4^{\text {th }} 2018$ Algeria, 2018) in 2017.

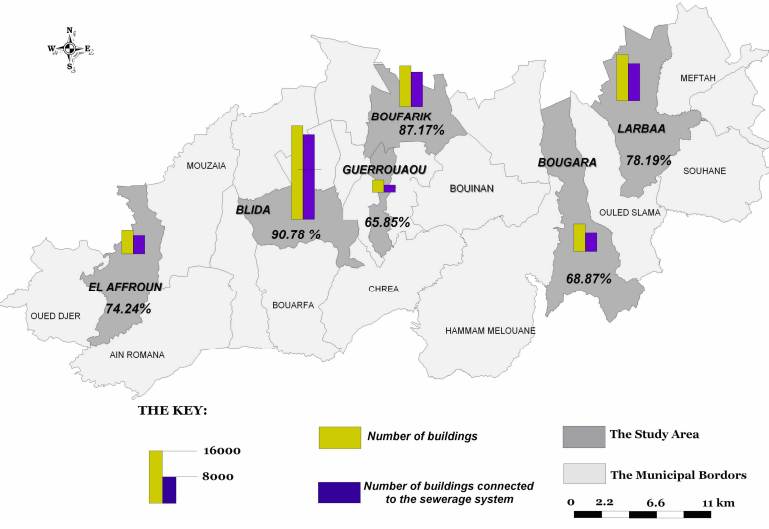

Fig. 5. Number of buildings connected to the sewerage system in Blida province in 2017.
The problems related to the connection to the sewerage system in the study area had a negative impact on environment. We noticed the pollution of most valleys and waterways with waste waters as seen in the pictures below (Fig. 6 and Fig. 7).

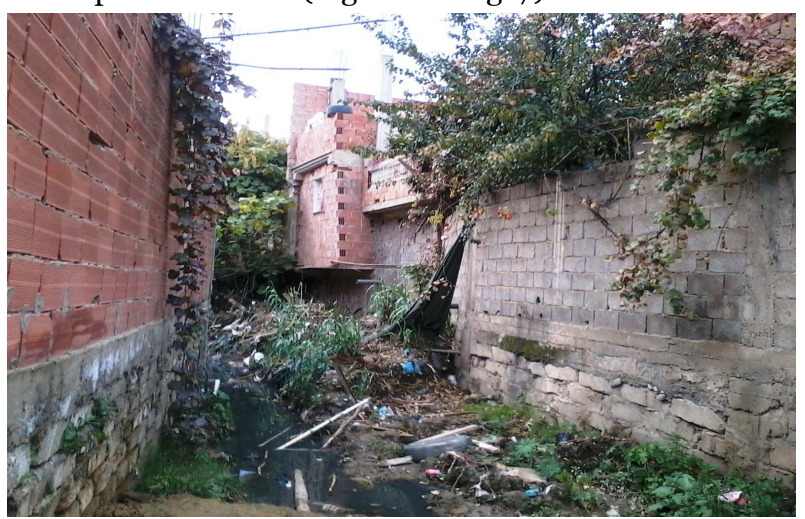

Fig. 6. Pollution of Guerouaou valley with waste waters (source: the authors, March, $14^{\text {th }} 2017$ ).

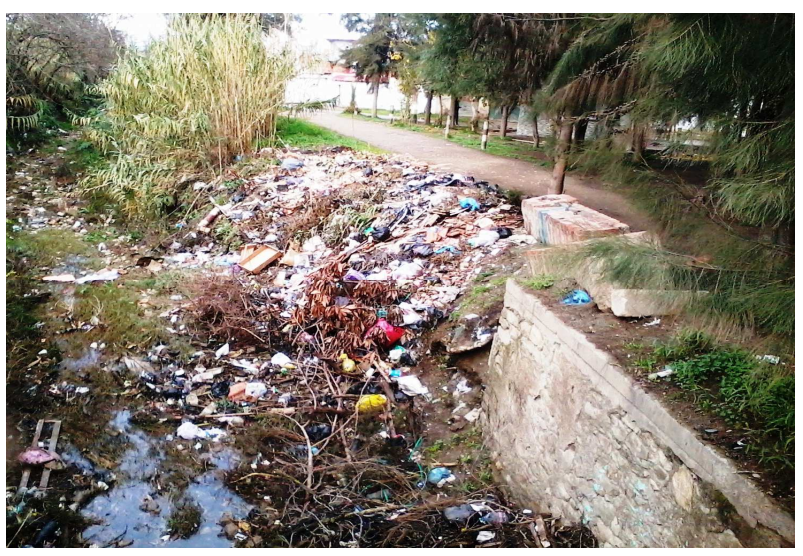

Fig. 7. Pollution of Bouchmal valley in the municipality of Boufarik (source: the authors, December $7^{\text {th }}$ 2016).

Second, the study area suffers from the spread of arbitrary construction in its urban area. Arbitrary constructions are considered as fragile habitations, which are built with materials that consist mainly of remains of cans and collected at the edges of some industrial cities (Gherbi, 2012). This is illustrated in Figure 8.

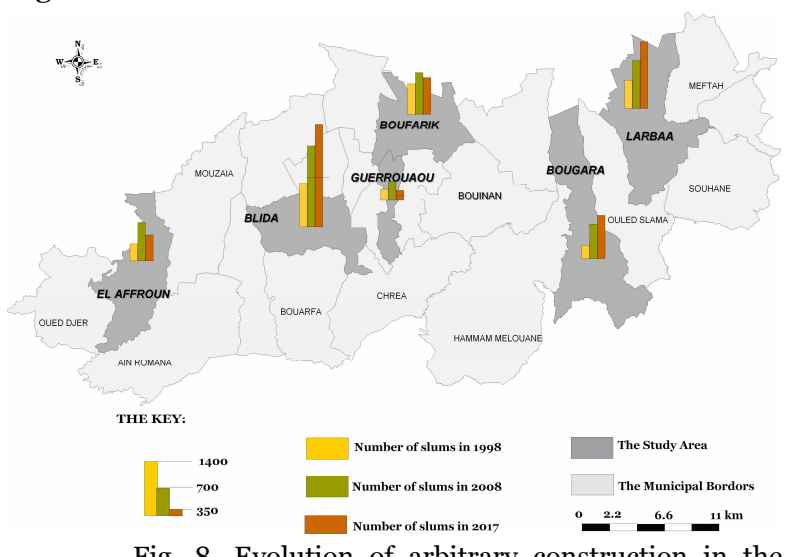
study area municipalities in the period 1998-2017. 
The arbitrary construction phenomenon (see some anarchist buildings in the area of study, explained in figure 9) is growing rapidly in the study area, with a total of 4,379 arbitrary buildings recorded in 1998, rising to 8,690 in 2017 (Official Bulletin no. 21-2018, Directorate of Construction and Urbanism, Blida State, 2018). This terrible growth is due to the housing crisis, as well as the lack of periodic surveillance for violations by the competent authorities.

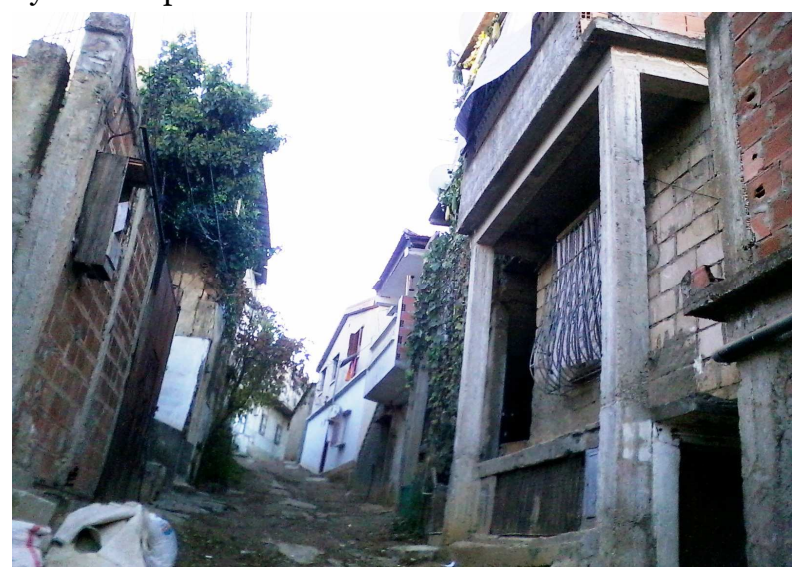

Fig. 9. Arbitrary construction in El-Afroun Municipality (source: the authors, November $4^{\text {th }}$, 2016).

\section{RESULTS AND DISCUSSION}

\subsection{The inhabitants' degree of awareness and knowledge of the guidelines related to urban planning preparation}

The blueprint for space-planning and rehabilitation aims at achieving a healthy, safe and appropriate urban environment that includes the rules of use, height, size, and density to create harmonious and integrated urban harmony (Dubois-Maury, 1996).

The results of the surveys gave us a picture of the poor awareness of the population (see the results of the poll in Table 2), so that the population's knowledge of the most important urban planning tools was $6.70 \%$, a very low proportion reflecting the low frequency of popular participation in the preparation of spaceplanning and rehabilitation blueprint, with the highest percentage in the Blida municipality with $10.76 \%$, which is the metropolitan municipality, while the Guerrouaou municipality has the lowest rate with $2.42 \%$. This is due to the rural nature of the municipality.

Table 2. Percentage of population's awareness of blueprint for space-planning and rehabilitation in some Municipalities of Blida province (2017).

\begin{tabular}{l|rrrr}
\multicolumn{1}{c|}{ Municipalities } & $\begin{array}{r}\text { Number of inhabitants } \\
\text { (2015) }\end{array}$ & $\begin{array}{c}\text { Number of inhabitants } \\
\text { taking the survey }\end{array}$ & $\begin{array}{c}\text { Survey percentage \% } \\
\text { population knowledge } \\
\text { of the scheme }\end{array}$ \\
\hline BLIDA & 176,767 & 9,033 & 5.11 & 10.76 \\
LARBAÂ & 102,899 & 5,155 & 5.01 & 7.12 \\
BOUFARIK & 79,518 & 4,159 & 5.23 & 8.96 \\
BOUGARA & 57,324 & 2,838 & 4.95 & 6.58 \\
EL - AFROUN & 45,616 & 2,340 & 5.13 & 4.36 \\
GUERROUAOU & 21,633 & 1,030 & 4.76 & 2.42 \\
TOTAL & 483,757 & 24,554 & 5.08 & 6.70 \\
\hline
\end{tabular}

Source: the authors (field work, 2016-2017)

The low percentage of the population's knowledge space-planning and rehabilitation blueprint (Fig. 10), gives us an answer to some of our questions: the community is directly responsible in increasing the frequency and effectiveness of popular participation in the preparation of urban planning tools in Algeria.

There is no doubt that the development of local societies through popular participation requires first and foremost practical methods that are designed to create mutual understanding and mutual awareness between the members of the community who represent the beneficiaries of the projects, and with the officials of the local authorities who represent the executers responsible of implementing and guaranteeing the right maintenance of these projects (Wafa, 1988).

The actual and practical involvement of locals in the advancement of their communities is the basis for local development.

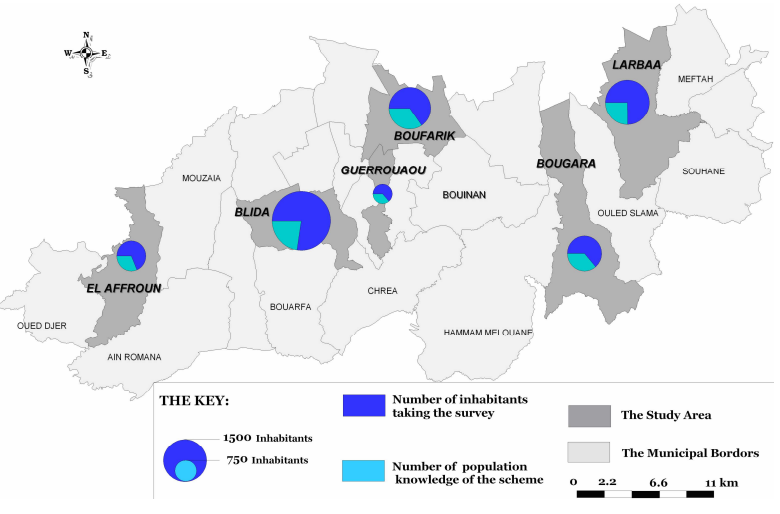

Fig. 10. Population knowledge of the Master Plan for Rehabilitation and Reconstruction of some Municipalities in the state of Blida.

By participation we do not only mean direction participation in development projects themselves, but 
also any positive behavior from individuals is considered as indirect participation in the development process.

The continuous increase in participation is associated with a very important factor, and that is the increase of the degree of awareness about these planning tools and development program's importance for individuals and groups (Ashraf, 1996), as shown in Figure 11.
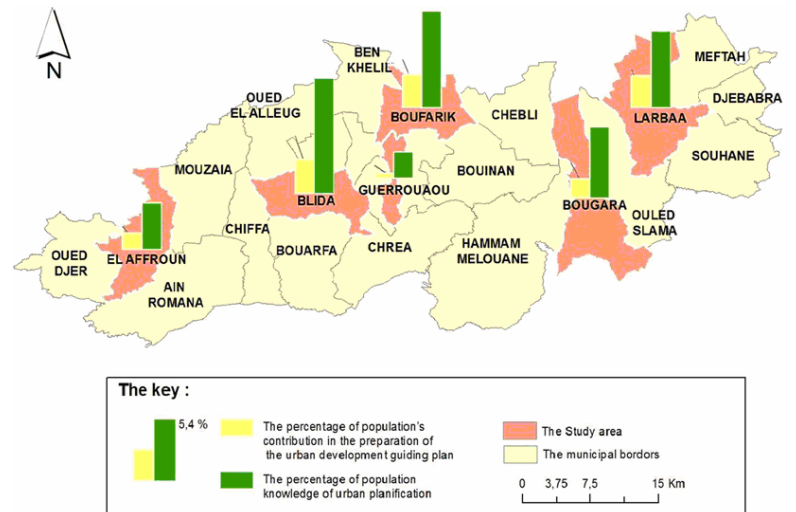

Fig. 11. The relationship between weak urban awareness with the weakness of popular participation in the preparation of the space-planning and rehabilitation of blueprints.

\subsection{Do people know that they have the right to participate in the preparation of the space- planning and rehabilitation blueprint?}

It is clear from the results of the survey that most of the inhabitants of the municipalities concerned do not know that they have the right to take part in the preparation of the space-planning and rehabilitation blueprint (as shown in Figure 12), so we recorded a very low percentage of the population to be able to take part and to express opinion in the preparation of the spaceplanning and rehabilitation blueprint. The percentage was estimated at $4.83 \%$ in Blida and Boufarik, respectively $7.52 \%$ and $7.17 \%$, while the Municipality of Guerrouaou was the weakest rated at $1.29 \%$, due to its poor educational level.

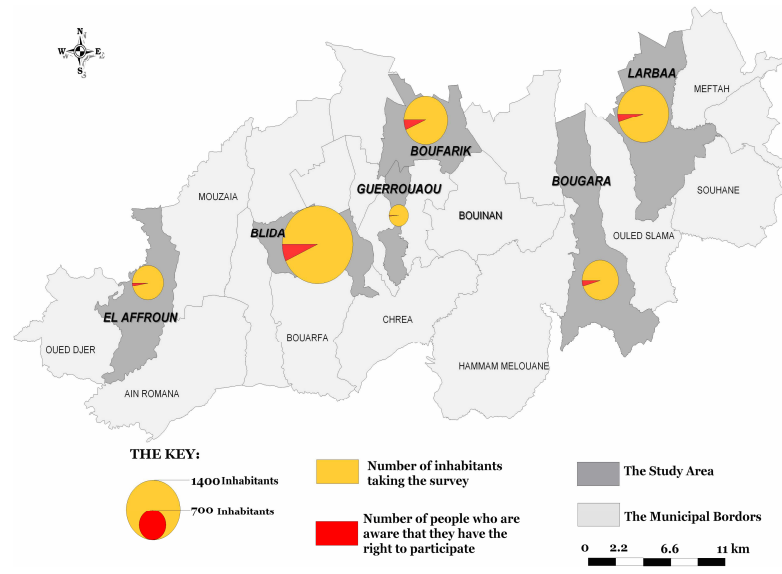

Fig. 12. Population knowledge ratio of the possibility of their participation in the preparation of the space-planning and rehabilitation blueprint.
When popular participation is adopted as a policy for implementing projects and preparing urban plans within society, many obstacles may limit the success of this process. The members of the participating community may not be fully formed, thereby hindering the success of popular participation (Anuar and Saruwono, 2013). We observed that the population of the municipalities in Blida province is poorly informed about their possibility of participation in the preparation of urban plans. This observation is confirmed by the mayor of Larbaâ (2017), affirming: "we have recorded an absence of the citizens' will to express their opinions about the preparation of the municipal space-planning and rehabilitation plan; although they suffer from a lot of urban problems such as connection to sewage systems".

\subsection{The weak popular participation in the preparation of space-planning and rehabilitation blueprint}

The municipalities concerned reviewed the preparation of the blueprint for space-planning and rehabilitation during the period from 2009 to 2014, according to the Algerian state policy, which during the period reviewed 1041 of the 1541 municipalities located in the national territory (Official Bulletin of the Ministry of Housing, Urban and City, 2015).

The percentage of popular participation in the preparation of the space-planning and rehabilitation blueprint of the municipalities of Blida, Boufarik, Bougara, el-Afroun, is very weak and described in Figure 13 .

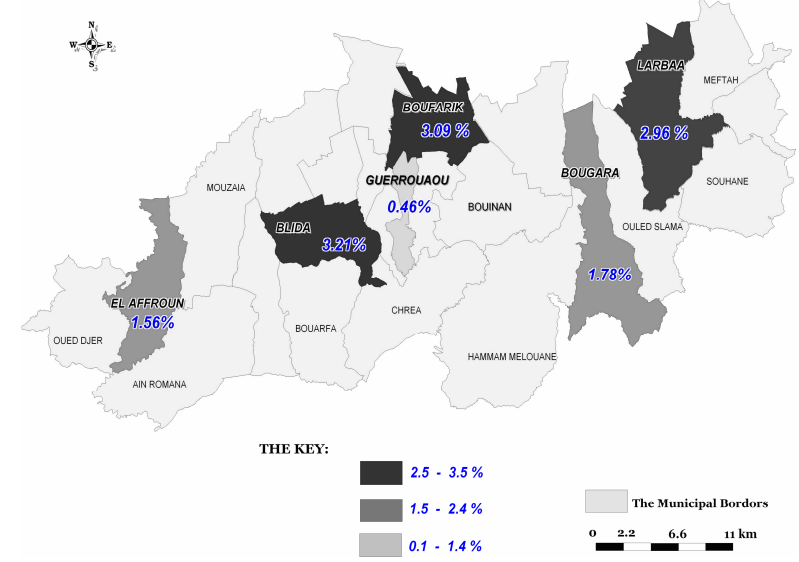

Fig. 13. The percentage of popular participation in the preparation of the guidelines for the preparation and reconstruction of some municipalities in the State of Blida.

The results of the public participation rate in the preparation of the blueprint for space-planning and rehabilitation are very low at $2.17 \%$ at the level of the municipalities concerned, and a percentage that reflects the degree of a citizen's involvement with its urban area and its knowledge of its problems. Any urban policy derives its spirit from the daily life of the citizens by identifying their concerns and taking their views and 
seeking their assistance in the management of public life (Alouat, 2015).

The lack of popular participation reflects the weak awareness of the local community in urban culture or gives negative signals of mistrust between the population and the local public authorities. This is due to the population's idea of the futility of participating in the preparation of urban planning tools and the superficiality and marginalization of its participation in changing and enriching the draft preparation of the outline plan.

The weakness of popular participation in the study area through the preparation of the spaceplanning and rehabilitation plan is due to some obstacles and restrictions that affect the effectiveness and degree of participation. These restrictions are related either to the newness of the idea of work as participation, or to the participants themselves or the local authorities responsible for running local affairs. Thereby, cooperation between the participants' parts in the preparation of urban planning demonstrates its importance (Turner, 1988).

The purpose of any cooperation between participating parties must stem from the desire to raise the quality of life of the poor urban classes and to facilitate their access to material resources that can contribute to the improvement of their deteriorating living conditions (Davidson and Peltenburg, 1993).

\subsection{Building trust as an important parameter for participation efficiency}

Trust is most commonly defined as a belief or expectancy regarding the attitudes, the future behavior, and the performance of an object of trust (Lewicki et al., 2003). Building of trust is sometimes regarded as the genuine benefit of participatory processes because of its presumed positive influence on social relations, systems, and psychological functioning, that goes even beyond the current planning process (Carr et al., 1998). Given that participation is a process of social interaction involving different actors, trust represents a crucial aspect in structuring mutual relationships. As such, trust may facilitate an open dialog and productive cooperation among different actors as well as influence public support for decisions and projects (Brockner et al., 1997). Trust is a complex phenomenon that consists of diverse dimensions, refers to different objects, and is often assumed to develop gradually over time from a low level of initial trust at the beginning of interaction towards a higher level which is knowledge-based (Lewicki and Bunker, 1996). Usually the perception of trust-related attributes or dimensions of trust, such as transparency, openness, competence, and reliability are assessed as empirical indicators for trust.

Based on Figure 14, for instance, we recorded in the municipality of Blida $60.03 \%$ of distrust in the population, which negatively impacts popular participation by $3.21 \%$. In the municipality of Boufarik, we recorded a percentage of distrust of nearly $69 \%$, that is only $30 \%$ of the inhabitants trust their local officials; leading to a low rate of popular participation in urban planning in Boufarik by $3.09 \%$.

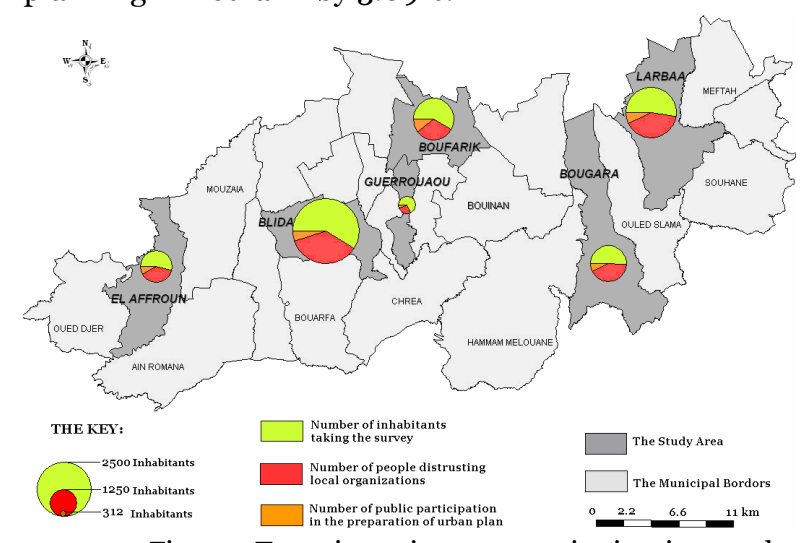

Fig. 14. Trust is an important criterion in popular participation in the study area.

According to the deputy mayor of Boufarik (2017), the weakness of popular participation in urban development is mainly due to the organizing legal aspect of operation of urban planning, as well as the lack of confidence of the citizens in local authorities because of the municipality's inability to meet their various needs which is due to the municipality's low budget.

\section{CONCLUSION}

Popular participation in the preparation of urban planning tools means that development plans and projects should be the result of positive negotiations between public authorities and citizens, where participation is based on an essential concept: an environment gives better results if its inhabitants contribute to its establishment and management rather than being just inactive consumers (Shabka, 1991). Henry Sanoff defined it as face-to-face interaction between individuals who share a number of values important to all, that is to say a purpose for them being together (Sanoff, 1990).

Algeria has relied on the experience of popular participation in the preparation of urban planning tools since 1990 in accordance with the Law no. 90-29 on Spatial and Urban Planning (Law no. 90-29, 1990), where it adopted its method of public consultation and investigation. The level of participation is classified according to Arnstein Cherry's hierarchy (Arnstein, 1969) and United Nations Classification 1989 (United Nations Centre for Human Settlements, 1989). The level of participation in Algeria corresponds to the consultation model, which allows the participation of the population in the preparation of projects and urban plans, but to varying degrees. 
After examining the cases of some municipalities in Blida province about popular participation in the preparation of the Spatial and Urban blueprint, we concluded that the approach used to involve the local citizen in the preparation of urban plans lacks many points which are considered fundamental to the community partnership process. These are: training, transparency, commitment, undertaking, accountability and continuity. This reduces the effectiveness of participation.

The promotion of popular participation in the preparation of urban development plans remains the responsibility of everyone in the government, local authorities, the private sector, associations and nongovernmental organizations, as well as different segments of society.

We also recorded a low contribution to popular participation in the preparation of urban plans, and this is due to many factors some of which are the organizing legal framework of urban planning, the weakness of urban awareness in most of the population. Only $6.70 \%$ of the total population in the municipalities have knowledge about urban planning. That is a very low percentage reflecting the local population's degree of interest for urban planning and projects, although they suffer much from various issues and problems in urban planning like the problem of sewerage networks and their impact on the urban space of the study area. Another problem is the increase of arbitrary constructions. Despite of all these problems, the local population does not participate in the preparation of Urban Space and Rehabilitation plans; only 2.05\% of the total population of the municipalities in the study area. In order to activate and raise popular participation in Algeria from its symbolic level to actual participation in decision making, we recommend the following:

- mobilizing the population to participate using local publicity and material and moral incentives to guarantee participation encompasses most of the local society;

- publish all the results and observations from public investigations and consultations on the preparation of urban planning tools in a transparent manner without any bias or pressure;

- preparing and training the population to execute and participate in urban projects continuously and periodically;

- modify the legal framework to facilitate and encourage the population to participate in various local development programs;

- encourage and support popular groupings in the form of associations and non-governmental organizations which active role is to make decisions relative to urban development;

- support cooperation between the different basic organizations and all the parties concerned by decision-making relative to urban plans and projects by defining the roles, responsibilities and missions of each organization and avoid interference and opposition in these roles because this can be one of the major negative factors that impact on the effectiveness of popular participation.

\section{REFERENCES}

Adja D., Drobenko B. (2007), Droit de l'urbanisme Les conditions de l'occupation du sol et de l'espace, l'aménagement, le contrôle, le financement, le contentieux. [Planning law on the conditions of land use and space, planning, control, financing, litigation], Publisher: Berti, Algeria, p. 137, ISBN: 978.9961. 69.121.0.

Alouat M. (2015), Sustainable urban development and dynamics of local dealers in the capital of Algiers. Ph.D. thesis. Houari Boumediene University of Science and Technology, Algiers, 2015, p. 213. (printed version)

Arnstein S. R. (1969), A Ladder of Citizen Participation. JAIP, 35(4), 216-224.

Ashraf M. (1996), Renewal and Revitalization of Residential Areas in Developing Countries. Letter from Magister Cairo, Egypt. P. 113.

Baloh T. (2013), Primerjalno-pravni pregled sistema prostorskega načrtovanja glede sodelovanja javnosti, Ljubljana. [Comparative legal review of the spatial planning system regarding public participation], Pravno-informacijski center nevladnih organizacij PIC. URL: http://zagovorniki-okolja.si/wp-content/ uploads/2018/11/Primerjalnopravna-ureditev-sodelo vanja-javnosti-pri-prostorskem-na\%C4\%8DrtovanjuTeja-Baloh.pdf. Accessed on: 01/o9/2018.

Bouzahzah N., Bouzahzah F. (2008), The participation of the inhabitants of the Algerian city: from the speech... to the Act. Proceedings of the International Conference on Architecture and Sustainability, BISKRA Mohamed Karande University, Algeria, 8-10 April 2008, pp. 449-458.

Brockner J., Siegel P. A., Daly J. P. Tyler T., Martin C. (1997), When trust matters: the moderating effect of outcome favorability. Administrative Science Quarterly, 42(3): 558-583.

Carr D. S., Selin S. W., Schuett M. A. (1998), Managing public forests. Understanding the role of collaborative planning. Environmental Management 22 (5): 767-776. DOI: 10.1007/s002679900146

Davidson F., Peltenburg M. (1993), Government and NGOs/CBOs working together for better cities. Institute for Housing and Urban Development Studies (IHS), no. 6, Rotterdam Netherlands. Retrieved from: https://www.ihs.nl/sites/corporate/files/IHS_WP_oo 6_Government_NGO_s_and_CBO_s_Working_Toget her_for_Better_Cities_1993.pdf

Directorate of Construction and Urbanism of Blida State (2018), Official bulletin No. 21 of 2018 published by the Directorate of Construction and 
Urbanism of Blida State, on September $19^{\text {th }} 2018$. Dubois-Maury J. (1996), Urban planning, legal tools and urban form. Paris, p. 51.

Forester J. (1988), Planning in the Face of Power. Berkeley, University of California Press.

General Secretariat of the Government of Republic of Algeria (2006), Law No. 06-06, portant loi d'orientation de la Ville of March 12, 2006 [Law on the Orientation Law of the City], Official Bulletin of Republic of Algeria. URL: https://www.joradp.dz/FTP/ JO-FRANCAIS/2006/F2006015.pdf?znjo=15, Accessed on: 02/03/ 2016.

General Secretariat of the Government of Republic of Algeria (1990), Law no. 90-29 relative à l'aménagement et l'urbanisme of 01/12/1990 [The law relating to planning and urban planning]. Official Bulletin of Republic of Algeria. URL: https://www. joradp.dz/FTP/JO-FRANCAIS/1990/F1990052.pdf? znjo=52, Accessed on: 09/01/2016.

General Secretariat of the Government of Republic of Algeria (1990), Law no. 90-25, (1990) portant orientation foncière of 18 / 11/ 1990 [Law on real estate guidance]. Official Bulletin of Republic of Algeria. URL: https://www.joradp.dz/FTP/JOFRANCAIS/1990/F1990049.pdf?znjo=49, Accessed on: 26/O2/ 2016.

Gherbi B. (2012), Anarchist construction in Algeria. Letter from magister, University of Algiers No. 01, Algeria, p o8, URL: http://biblio.univ-alger.dz/ jspui/bitstream/1635/14868/1/GHERBI_BRAHIM.pdf. pdf. Accessed on: 03/10/2018.

Golobič M., Marušič I. (2007), Developing an integrated approach for public participation: a case of land-use planning in Slovenia. Environment and Planning B: Urban Analytics and City Science 34(6): 993-1010. DOI: http://dx.doi.org / 10.1068/b32080.

Habib Tarek Galal (2009), Evaluation of the effectiveness of social participation in the projects of strategic planning of Egyptian villages. Journal of Engineering Sciences, Assiut University, 37(2), 463482, March 2009. URL: http://www.aun.edu.eg/ journal_files/20_J_238.pdf. Accessed on: 22/02/ 2016 Hattab S. (2014), Instruments of urban planning theory and practice, case: Bousaada, Algeria. International Journal of Planning, Urban and Sustainable Development, 1(1), 1-10.

Knieling J., Othengrafen F. (eds.) (2009), Planning cultures in Europe. Decoding cultural phenomena in urban and regional planning. Farnham. Surrey. Ashgate.

Lewicki R., Gray B., Elliott M. (2003), Making sense of intractable environmental conflicts, Concepts and Cases. Island Press, Washington.

Lewicki R. J., Bunker B. B. (1996), Developing and Maintaining Trust in Work Relationships. In: Kramer, R. M. and Tyler, T. R., Eds., Trust in Organizations: Frontiers in Theory and Research, Sage Publications,
Thousand Oaks, 114-139. http://dx.doi. org/10.4135/9781452243610.n7. Accessed on: 17/01/ 2019.

Ministry of Housing, Urban and City (2015), Official Bulletin of the Ministry of Housing, Urban and City issued on 25 November 2015 in Algeria, p. 49.

Ministry of Irrigation of the Algerian State (2018), Official bulletin no. 38 of February $4^{\text {th }} 2018$.

Mohamed Anuar M. I. N, Saruwono M. (2013), Obstacles of Public Participation in the Design Process of Public Parks. Journal of Asian Behavioural Studies, 3(8): 89-99. Retrieved from: https://fspu.uitm.edu.my/ cebs/images/stories/cebs/jabsv3n8c9.pdf

Monédiaire G. (2011), La participation du public organisée par le droit: des principes prometteurs, une mise en œuvre circonspecte. Participations, 1(1), 134155. doi:10.3917/parti.001.0134.

Mosilhi F. M. (2008), Geography of Urbanism from a contemporary geographic and developmental perspective. Dar Al Majid Publishing and Distribution, Egypt, p. 375 .

National Statistical Office (2008), General Population and Housing Census, statistical collection no. 163-2011, urban frame Algeria. URL: http://www.ons.dz/IMG/pdf/armature_urbaine_20o8 .pdf. Accessed on: 4/01/2018.

National Land Use Planning Agency (2012), Wilaya of Blida Development Plan. Report no. 01, April 2012, Algeria (printed version).

National Assembly of the Parliament of France (2000), Law no. 2000-1208 relative à la solidarité et au renouvellement urbain [Law on urban solidarity and renewal of 13/12/200o] Paris, France. URL: https://www.legifrance.gouv.fr/affichTexte.do?cidTexte =LEGITEXToooo05630252. Accessed on: 06/07/ 2017.

National Assembly of the Parliament of France (2010), Law no. 2010-788 portant engagement national pour l'environnement (1). [Law on National Commitment to the Environment (1) of 12 / 07/ 2010] Paris, France, URL: https://www.legifrance.gouv.fr /affichTexte.do?cidTexte=JORFTEXToooo22470434, Accessed on: 07/07/ 2017.

Popular Assembly of the State of Blida (2018), Official Bulletin of the State of Blida, no. 23 of September $20^{\text {th }} 2018$ (printed version).

Republic of Slovenia (1967), Zakon o urbanističnem planiranju [Law on Urban Planning]. Uradni list Socialistične Republike Slovenije 26/1967. [Official Bulletin of the Socialist Republic of Slovenia]. Ljubljana.

Shabka S. H. (1991), An Approach to Users Responsive Housing in The Egyptian Context. Unpublished Ph. D. Thesis in Architecture, Cairo University, Printed varsion.

Saidouni M. (2010), Éléments d'introduction à l'urbanisme: histoire, méthodologie, réglementation 
[Elements of introduction to urban planning, history, methodology, regulation ], Kasbah Edition, Algeria, p. 136. ISBN: 9961-64-235-X. URL: https://casbaheditions.com/fr/Catalogue/el\%C3\%A9ments-d\%E2\% 80\%99introduction-\%C3\%Ao-1\%E2\%80\%99urbanisme Accessed on: 29/03/ 2016.

Salama A. (2010), Public Participation as a Means of Archeological Heritage Preservation: Rosetta City as a Case Study, the International Forum on Technical and Sustainability in Urban Development. Riyadh, King Saud University, 3-6 January 2010, p. 228. URL: https://cap.ksu.edu.sa/sites/cap.ksu.edu.sa/files/attac h/tsbe_1_ar_13.pdf, accessed on: 02/04/ 2016.

Smith R. W. (1973), A theoretical basis for participatory planning, Policy Sciences 4 (3) 275-295.

Sanoff H. (1990), Participatory Design: Theory and Techniques, Bookmasters Inc., U.S.A.

Technical Department of the Municipality of Guerrouaou (2017), Report published by Guerouaoua municipality's technical services. March $06^{\text {th }} 2017$, Algeria.

Turner B. (ed.) (1988), Building Community: A Third World Case Book from Habitat International Coalition. Building Community Books, London.

Turowski G. (2002), Spatial planning in Germany: Structures and concepts. Studies in Spatial Development, 1, Verlag der ARL - Akademie für Raumforschung und Landesplanung, Hannover. Retrieved from: https://www.econstor.eu/bitstream/ 10419/59969/1/718937562.pdf
United Nations Centre for Human Settlements (1989), Community participation $\mathrm{n}$ problem solving and decision making leadership (UN-HABITAT). Nairobi. http://www.nzdl.org/gsdlmod?e=d-ooooo-oo---offohdl--oo-o-----0-10-0---0---odirect-10---4-------0-11-11-en-50---20-about---00-0-1-00-0--4----0-0-11-10outfZz-8-oo\&cl=CL1.3\&d=HASHo15defa88ef2d o6fe42f9994\&gt=1 . Accessed on: 13/o9/ 2018.

UNECE (1998), Convention on access to information, public participation in decision-making and access to justice in environmental matters. Aarhus, Denmark, 25 June 1998. Retrieved from: https://www.unece. org/fileadmin/DAM/env/pp/documents/cep43e.pdf. Accessed on: 15. 11. 2015.

Wafa A. (1988), Training Program to Encourage Popular Participation to Improve the Quality of the Environment in Some Popular Housing Areas in Cairo. Center for Social and Cultural Planning, National Planning Institute, Cairo, 1988.

Weingran C. (2007), Public participation in the remediation of the warfare related site Stadtallendorf conception, principles, experience. Proceedings $2^{\text {nd }}$ International Conference on Managing Urban Land, 25 to 27 April 2007, Theaterhous Stuttgart, Germany, pp. 235-246. URL: https://ris.utwente.nl/ws/portalfiles /portal/5389512/2007-Early-assessment-Jessica.pdf. 